\title{
Tetraphenylethene-Based Platinum(II) Bis-Triangular Dicycles with Tunable Emission
}

\author{
Chenyang Li, ${ }^{1}$ Hao Nian, ${ }^{1}$ Y unhong Dong,,${ }^{1} *$ Yawen Li, ${ }^{1}$ Beilin Zhang, ${ }^{1}$ Liping \\ $\mathrm{CaO}^{1,2,3, *}$
}

${ }^{1}$ Key Laboratory of Synthetic and Natural Functional Molecule Chemistry of Ministry of Education, College of Chemistry and Materials Science, Northwest University, Xi'an 710127, P. R. China

${ }^{2}$ State Key Laboratory of Luminescent Materials and Devices, South China University of Technology, Guangzhou 510640, P. R. China

${ }^{3}$ Guangdong Provincial Key Laboratory of Luminescence from Molecular

Aggregates, South China University of Technology, Guangzhou 510640, P. R. China

*e-mail: hongcao2006@163.com; chcaoliping@nwu.edu.cn

Table of Contents

Pages

NMR spectra

ESI-MS

$\mathrm{X}$-ray structure determination S7

Fluorescence, DLS, and SEM experiments $\mathrm{S} 10$ 


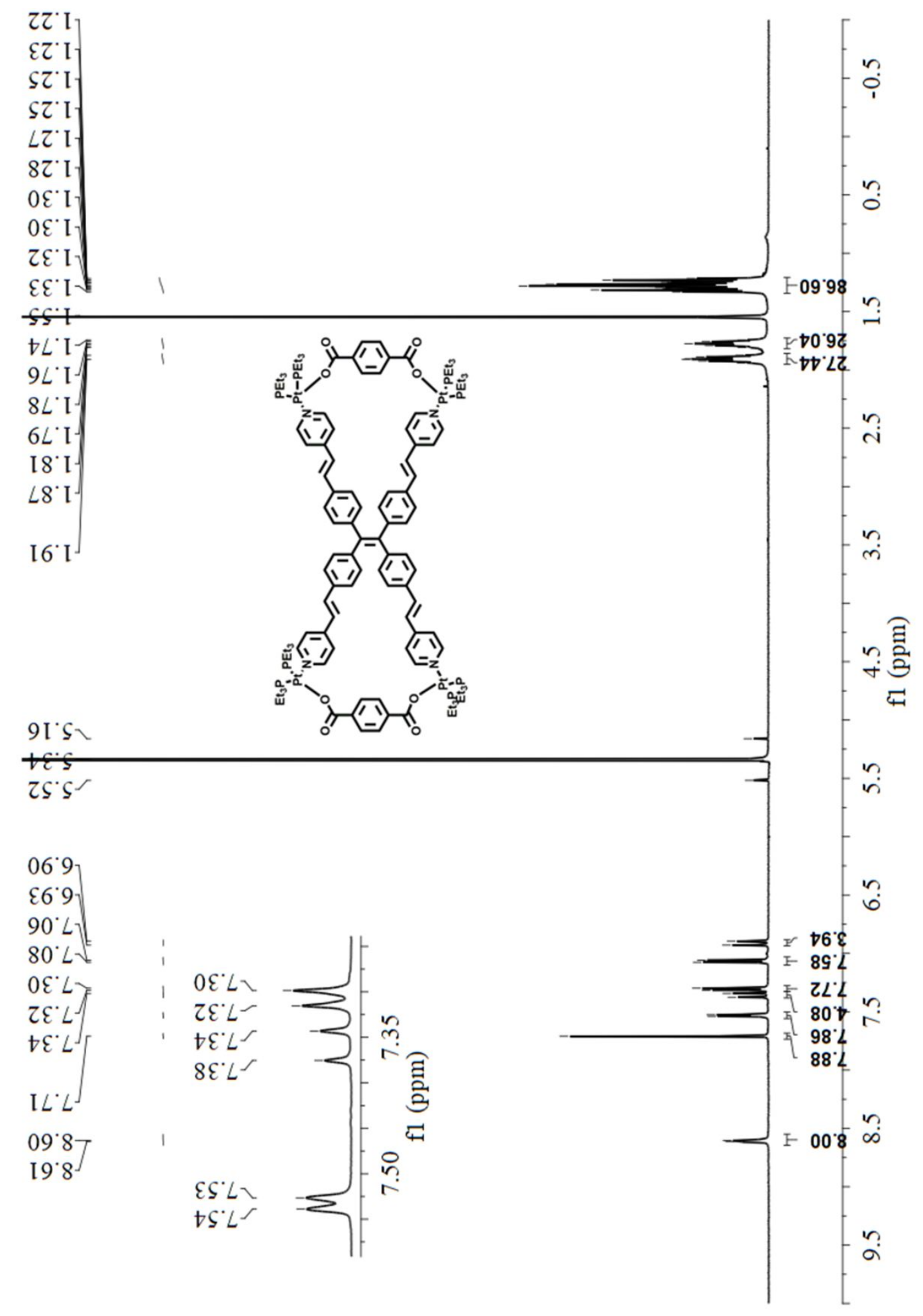

Figure S1. ${ }^{1} \mathrm{H}$ NMR spectrum $\left(\mathrm{CD}_{2} \mathrm{Cl}_{2}\right.$, room temperature, $\left.500 \mathrm{MHz}\right)$ of 1 
$920 \mathrm{I}^{*--}$

$28 \varepsilon^{--}-$

$88^{\wedge} \varepsilon$

$90 b^{\prime}$

$0 \varepsilon 6$

$86^{\circ} 6^{\circ}$

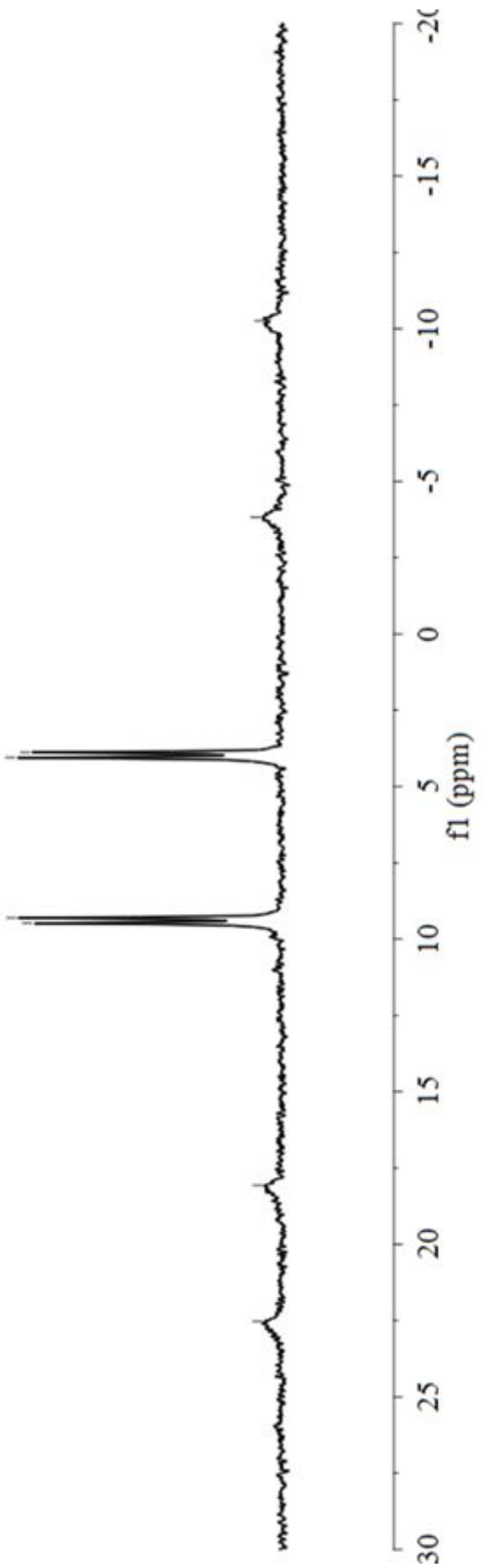

Figure S2. ${ }^{31} \mathrm{P}\left\{{ }^{1} \mathrm{H}\right\}$ NMR spectrum $\left(\mathrm{CD}_{2} \mathrm{Cl}_{2}\right.$, room temperature, $\left.121.4 \mathrm{MHz}\right)$ of 1 . 


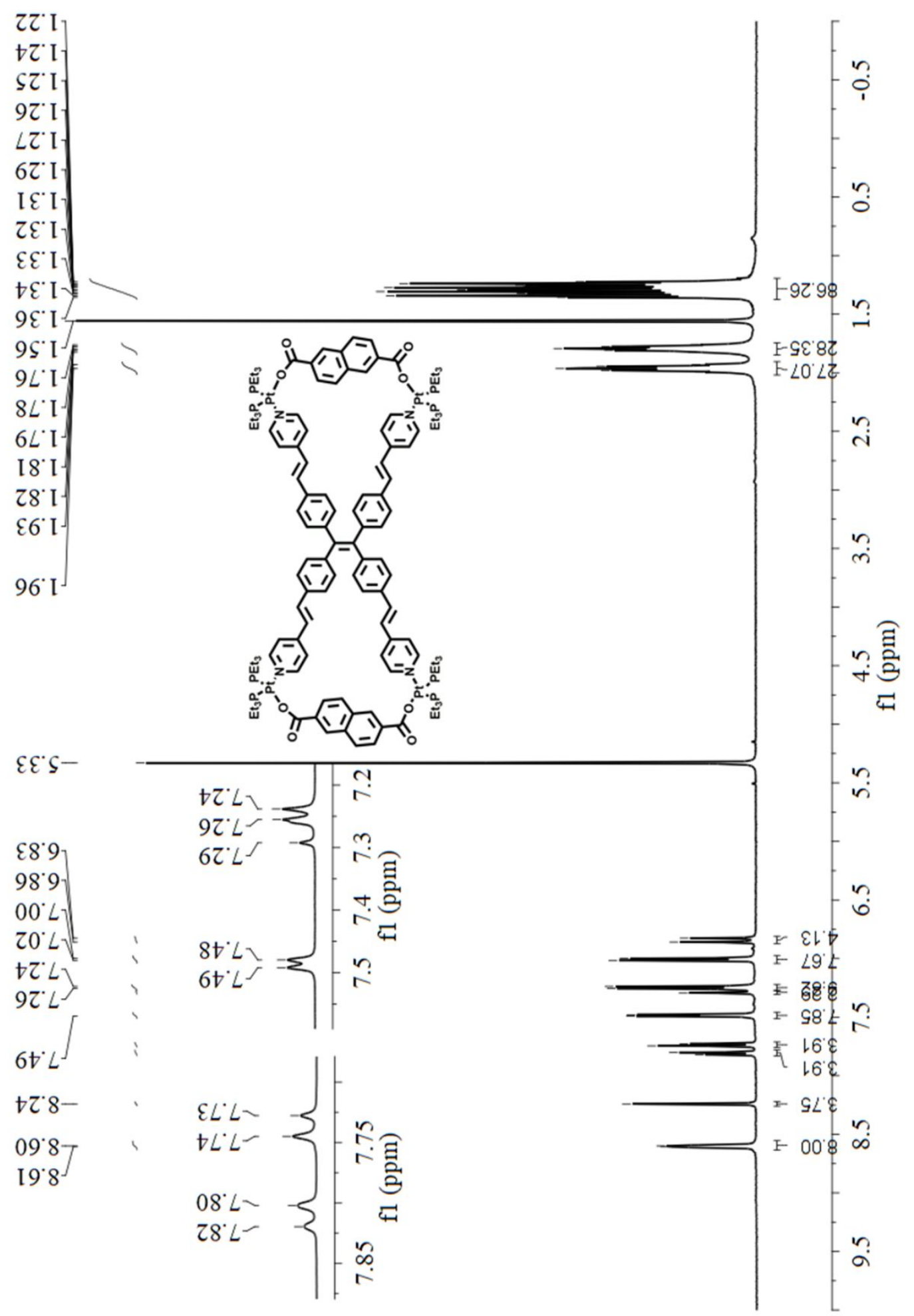

Figure S3. ${ }^{1} \mathrm{H}$ NMR spectrum $\left(\mathrm{CD}_{2} \mathrm{Cl}_{2}\right.$, room temperature, $\left.500 \mathrm{MHz}\right)$ of 2. 


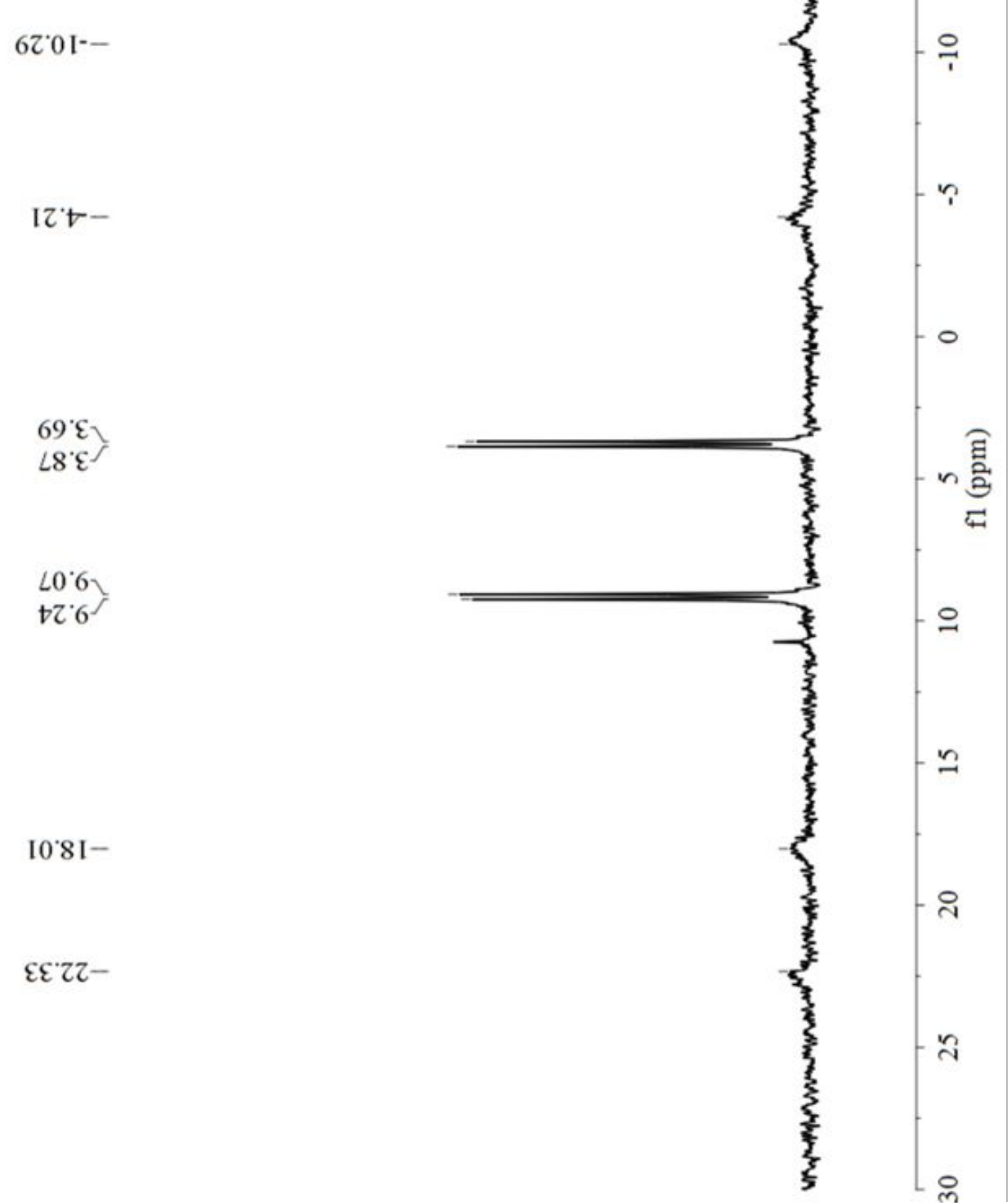

Figure S4. ${ }^{31} \mathrm{P}\left\{{ }^{1} \mathrm{H}\right\}$ NMR spectrum $\left(\mathrm{CD}_{2} \mathrm{Cl}_{2}\right.$, room temperature, $\left.121.4 \mathrm{MHz}\right)$ of 2 . 


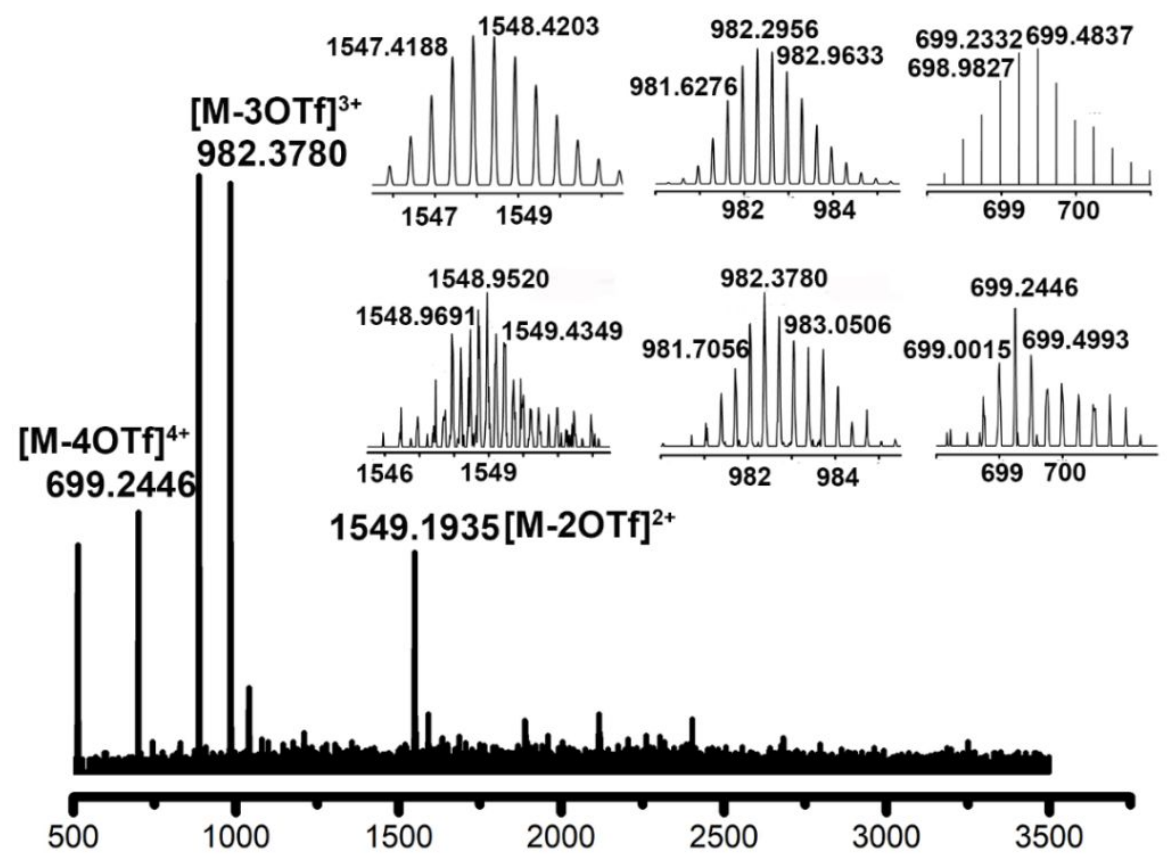

Figure S5. Experimental and calculated electrospray ionization mass spectra of $\mathbf{1}$.

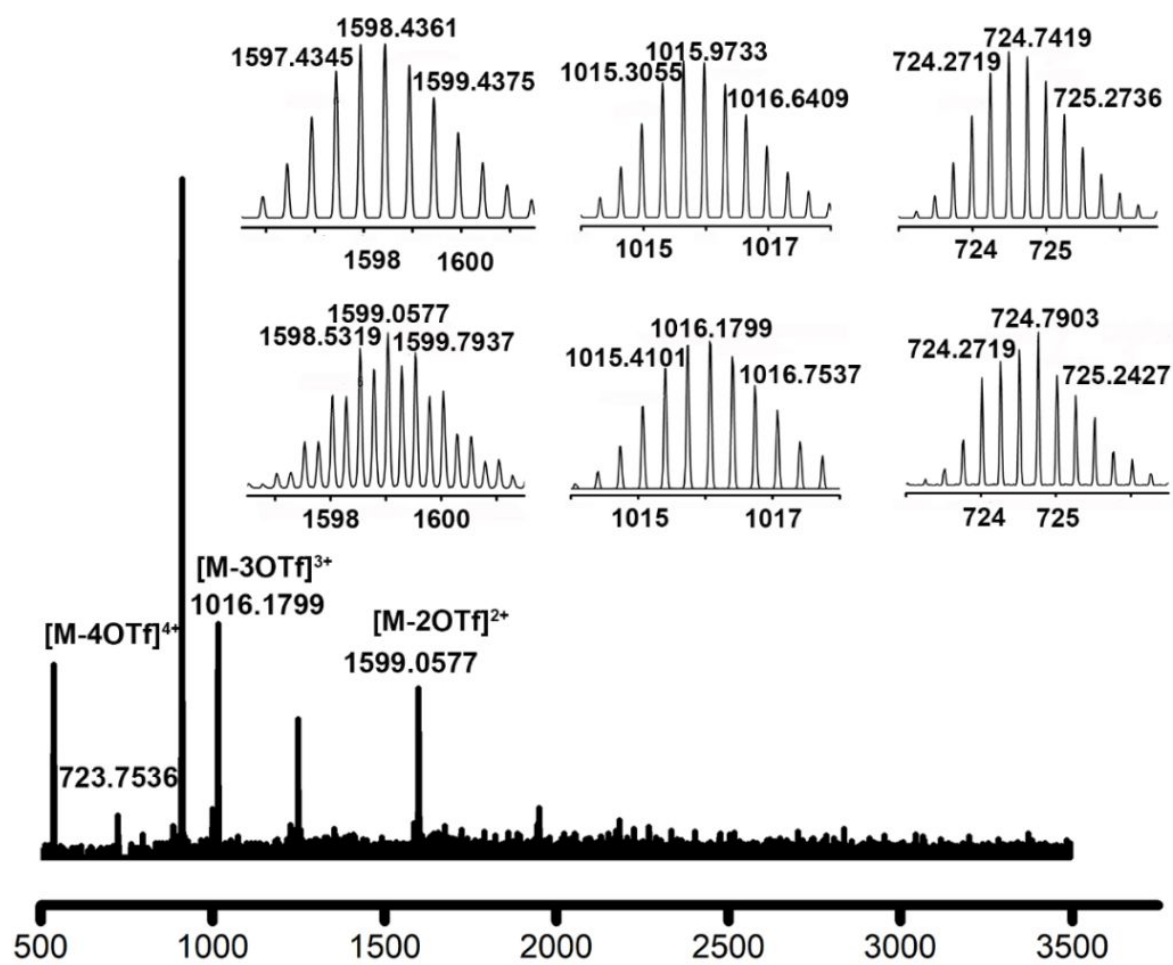

Figure S6. Experimental and calculated electrospray ionization mass spectra of 2. 


\section{X-ray Structure determination.}

Data collections was performed on Bruker VENTURE system with PHOTON 100 CMOS detector equipped and a Ga-target Liquid METALJET D2 PLUS X-ray Source $(\lambda=1.34139 \AA)$. The data was collected at $180 \mathrm{~K}$ crystal temperature (Oxford Cryosystems CRYOSTREAM 700), $50 \mathrm{kV}$ and $30 \mathrm{~mA}$ with an appropriate $0.5^{\circ} \omega$ and $\varphi$ scan strategy. Data reduction and integration were performed with SAINT (version 8.38A). ${ }^{4}$ Data was corrected for absorption effects using the empirical methods as implemented in SADABS (version 2016/2). ${ }^{5}$ The structure was solved by SHELXT (version 2018/2) ${ }^{6}$ and refined by full-matrix least-squares procedures using the SHELXL program (version 2018/3) ${ }^{7}$ through the OLEX2 ${ }^{8}$ graphical interface. All nonhydrogen atoms, including those in disordered parts, were refined anisotropically. All $\mathrm{H}$-atoms were included at calculated positions and refined as riders, with $U_{\text {iso }}(\mathrm{H})=1.2$ $U_{\text {eq }}(\mathrm{C})$ and $U_{\text {iso }}(\mathrm{H})=1.5 U_{\text {eq }}(\mathrm{C})$ for methyl groups. In each asymmetric unit, one triflate anion was found to be disordered and modeled with two orientations. The geometries of the disordered parts were restrained to be similar. The anisotropic displacement parameters of the disordered molecules in the direction of the bonds were restrained to be equal with a standard uncertainty of $0.004 \AA^{2}$. They were also restrained to have the same $U_{\mathrm{ij}}$ components, with a standard uncertainty of $0.01 \AA^{2}$. In each unit cell, there are 68 acetone molecules that were found to be severely disordered and removed by the SQUEEZE routine in PLATON (version 220719). ${ }^{9}$ The total void volume was $8584 \AA^{3}$ indicated by PLATON, equivalent to $40.32 \%$ of the unit cell's total volume. Further crystal and data collection details are listed in Table S2.

The crystal of 2: $2(4.2 \mathrm{mg}, 78.0 \mathrm{mmol})$ was dissolved in acetone $(1 \mathrm{~mL})$ and the solution was passed through a $0.45-\mu \mathrm{m}$ filter into a $10-\mathrm{mL}$ tube, which was placed inside a 500-mL wild-mouth bottle containing isopropyl ether $(20 \mathrm{~mL})$. The bottle was capped, after slow evaporation of isopropyl ether at room temperature into the acetone solution for 2 days, and light-yellow single cubic crystals of 2 were obtained. 
Table S1. Data and structure refinement parameters for $\mathbf{2}$

\begin{tabular}{|c|c|}
\hline \multicolumn{2}{|l|}{ Crystal data } \\
\hline Chemical formula & $\mathrm{C}_{181} \mathrm{H}_{274} \mathrm{~F}_{12} \mathrm{~N}_{4} \mathrm{O}_{37} \mathrm{P}_{8}$ \\
\hline$M_{\mathrm{r}}$ & 4482.39 \\
\hline Crystal system, space group & Monoclinic, $C c$ \\
\hline Temperature (K) & 180 \\
\hline$a, b, c(\AA)$ & $26.784(4), 22.700(3), 37.387(7)$ \\
\hline$\beta\left(^{\circ}\right)$ & $110.497(5)$ \\
\hline$V\left(\AA^{3}\right)$ & $21292(6)$ \\
\hline$Z$ & 4 \\
\hline$F(000)$ & 9152 \\
\hline$D_{x}\left(\mathrm{Mg} \mathrm{m}^{-3}\right)$ & 1.398 \\
\hline Radiation type & $\mathrm{Ga} K \alpha, \lambda=1.34138 \AA$ \\
\hline$\mu\left(\mathrm{mm}^{-1}\right)$ & 4.43 \\
\hline Crystal size (mm) & $0.18 \times 0.12 \times 0.06$ \\
\hline Diffractometer & Bruker D8 Venture PHOTON 100 CMOS \\
\hline Radiation source & Liquid METALJET D2 PLUS X-ray Source \\
\hline Scan method & $\phi$ and $\omega$ scans \\
\hline Absorption correction & $\begin{array}{l}\text { Multi-scan } \\
\text { SADABS2016/2 (Bruker,2016/2) was used for } \\
\text { absorption correction. }\end{array}$ \\
\hline$T_{\min }, T_{\max }$ & $0.875,0.956$ \\
\hline $\begin{array}{l}\text { No. of measured, independent and } \\
\text { observed }[I>2 \sigma(I)] \text { reflections }\end{array}$ & $97745,32249,31070$ \\
\hline$R_{\text {int }}$ & 0.054 \\
\hline$\theta$ values $\left({ }^{\circ}\right)$ & $\theta_{\max }=55.9, \theta_{\min }=2.3$ \\
\hline$(\sin \theta / \lambda)_{\max }\left(\AA^{-1}\right)$ & 0.617 \\
\hline Range of $h, k, l$ & $h=-32 \rightarrow 33, k=-28 \rightarrow 27, l=-46 \rightarrow 35$ \\
\hline \multicolumn{2}{|l|}{ Refinement } \\
\hline$R\left[F^{2}>2 \sigma\left(F^{2}\right)\right], w R\left(F^{2}\right), S$ & $0.036,0.086,1.05$ \\
\hline No. of reflections & 32249 \\
\hline
\end{tabular}

${ }^{\mathrm{a}} R 1=\Sigma|| F_{\mathrm{o}}|-| F_{\mathrm{c}}|| / \Sigma\left|F_{\mathrm{o}}\right| .{ }^{\mathrm{b}} w R 2=\left[\Sigma\left[w\left(F_{\mathrm{o}}{ }^{2}-F_{\mathrm{c}}{ }^{2}\right)^{2}\right] / \Sigma\left[w\left(F_{\mathrm{o}}{ }^{2}\right)^{2}\right]\right]$.

${ }^{\mathrm{c}}$ Quality-of-fit $=\left[\Sigma\left[w\left(F_{\mathrm{o}}^{2}-F_{\mathrm{c}}{ }^{2}\right)^{2}\right] /\left(N_{\mathrm{obs}}-N_{\text {params }}\right)\right]^{1 / 2}$, based on all data. 


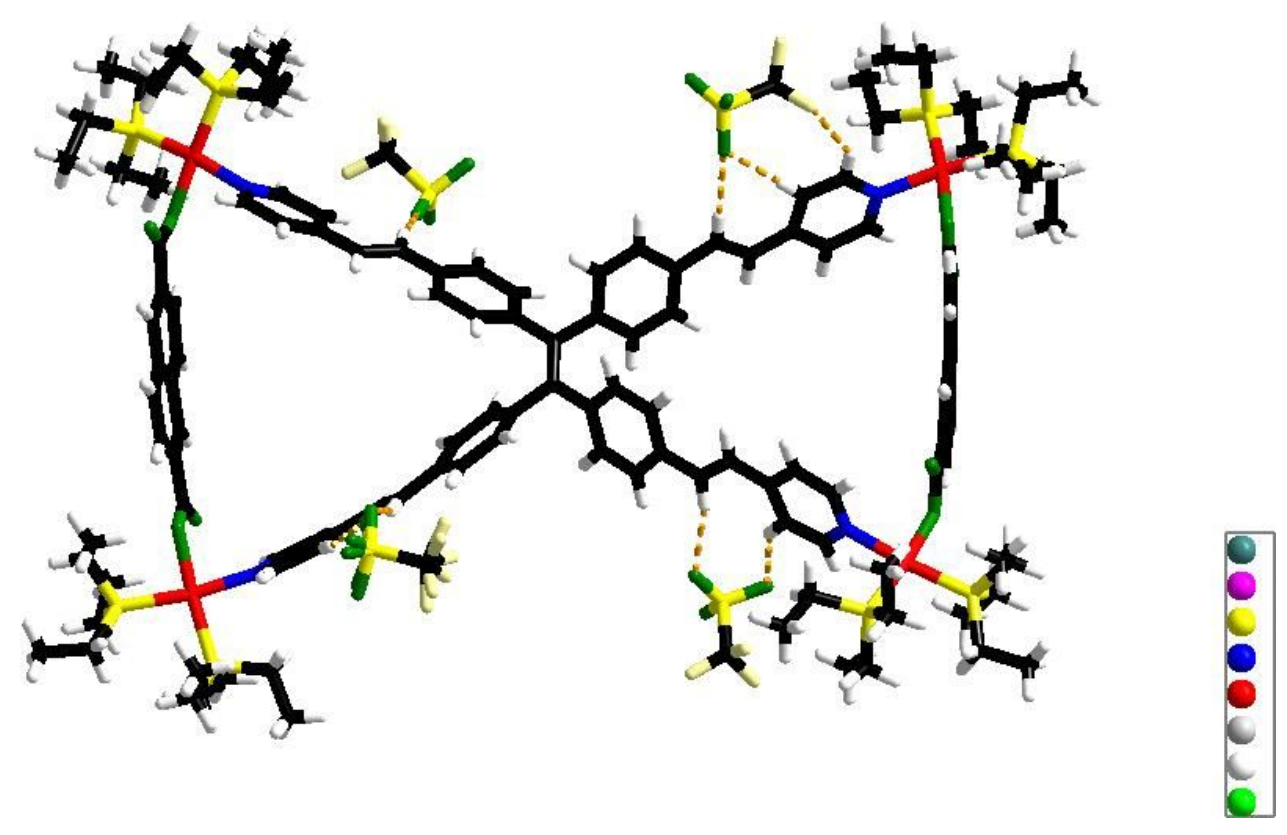

Figure S7. X-ray crystal structures of 2. Color: C, black; N, blue; Pt, red; O, green; P, yellow; H, white. 
Table S2. Quantum yields ( $\left.\Phi_{\mathrm{F}}\right)$ of $\mathbf{1}$ or $\mathbf{2}$ in different solvents.

\begin{tabular}{ccc}
\hline Solvent & $\mathbf{1}^{\mathrm{a}}$ & $\mathbf{2}^{\mathrm{b}}$ \\
\hline $\mathrm{DCM}$ & 0.823 & 0.339 \\
$\mathrm{EA}$ & 0.599 & 0.709 \\
$\mathrm{MeOH}$ & 0.354 & 0.220 \\
$\mathrm{MeCN}$ & 0.219 & 0.117 \\
$\mathrm{CHCl}_{3}$ & 0.579 & 0.598 \\
$1,4-$ dioxane & 0.684 & 0.580 \\
$\mathrm{THF}$ & 0.471 & 0.464 \\
\hline
\end{tabular}

${ }^{\mathrm{a} E x} / \mathrm{Em}$ slit $=3 \mathrm{~nm} ;{ }^{\mathrm{b}} \mathrm{Ex} / \mathrm{Em}$ slit $=3 \mathrm{~nm}$.

Fluorescence quantum yield was determined by using the emission intensity of the sample with that of a fluorescence standard using the following equation: $\Phi_{\mathrm{u}}=$ $\left(\Phi_{\mathrm{s}} \times \mathrm{A}_{\mathrm{s}} \times \mathrm{F}_{\mathrm{u}} \times \eta_{\mathrm{u}}{ }^{2}\right) /\left(\mathrm{A}_{\mathrm{u}} \times \mathrm{F}_{\mathrm{s}} \times \eta_{\mathrm{s}}{ }^{2}\right) . \Phi_{\mathrm{u}}, \Phi_{\mathrm{s}}, \mathrm{F}_{\mathrm{u}}, \mathrm{F}_{\mathrm{s}}, \mathrm{A}_{\mathrm{u}}, \mathrm{A}_{\mathrm{s}}, \eta_{\mathrm{u}}, \eta_{\mathrm{s}}$ are quantum yields, the integrated area under the corrected fluorescence spectra, the absorbance at the excitation wavelength, the refractive indexes of the solvents for the sample and reference, respectively. We used quinine sulfate in $0.1 \mathrm{M}$ sulfuric acid as the standard of quantum yield $(0.546$ at $313 \mathrm{~nm})$.

a)

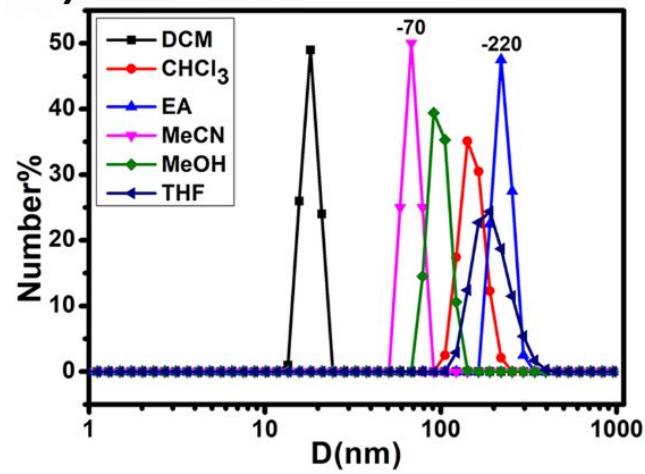

b)

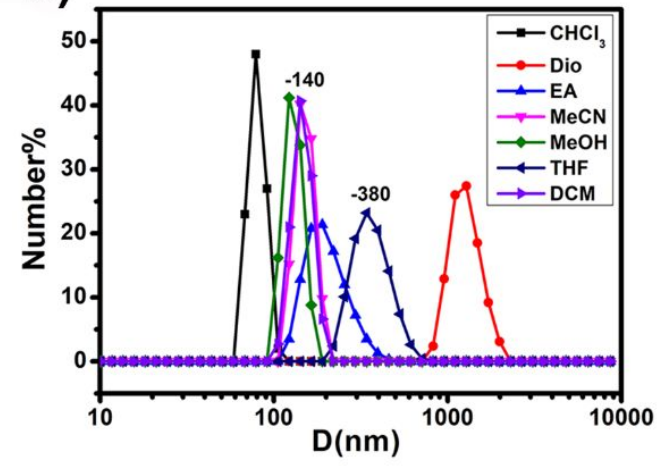

Figure S8. DLS profiles of the solution of (a) 1 and (b) 2 in different solvents including $1 \% \mathrm{CH}_{2} \mathrm{Cl}_{2}$. $[\mathbf{1}]=[2]=1.0 \times 10^{-5} \mathrm{M}$. 

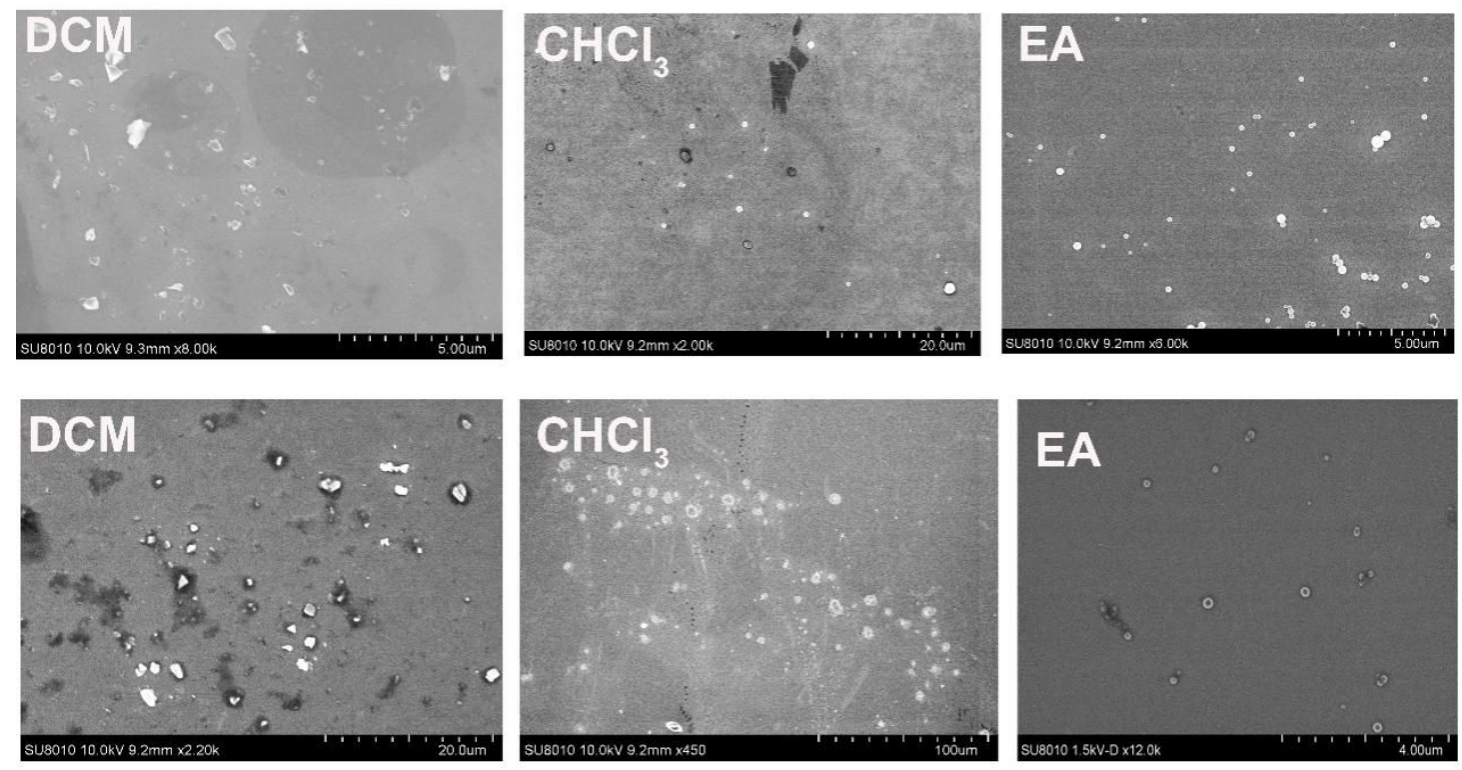

Figure S9. SEM images of $\mathbf{1}$ and $\mathbf{2}$ in different solvents including $1 \% \mathrm{CH}_{2} \mathrm{Cl}_{2}$. [1] $=[\mathbf{2}]$ $=1.0 \times 10^{-5} \mathrm{M}$.
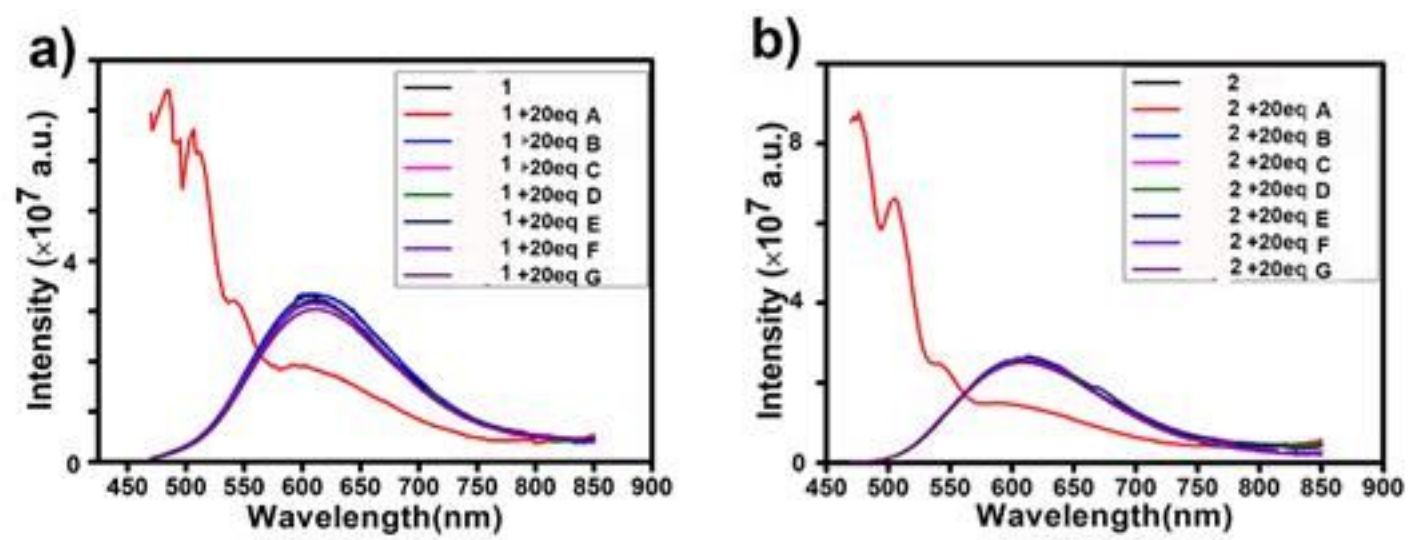

Figure S10. Fluorescence spectra of: (a) 1 and (b) 2 upon the addition of 20 equiv different guests in $\mathrm{CH}_{2} \mathrm{Cl}_{2}\left(\lambda_{\mathrm{ex}}=450 \mathrm{~nm}\right)$. [1] $=[2]=1.0 \times 10^{-5} \mathrm{M} . \mathrm{E}_{\mathrm{x}} / \mathrm{E}_{\mathrm{m}}$ slit $=2 \mathrm{~nm}$. [A (perylene), B (triphenylene), C (anthracene), D (naphthalene), E (pyrene), F (phenanthrene), G (coronene)]. 
a)

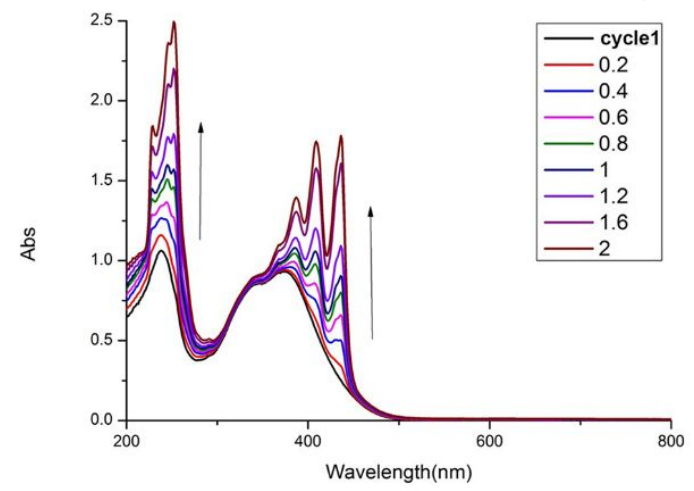

b)

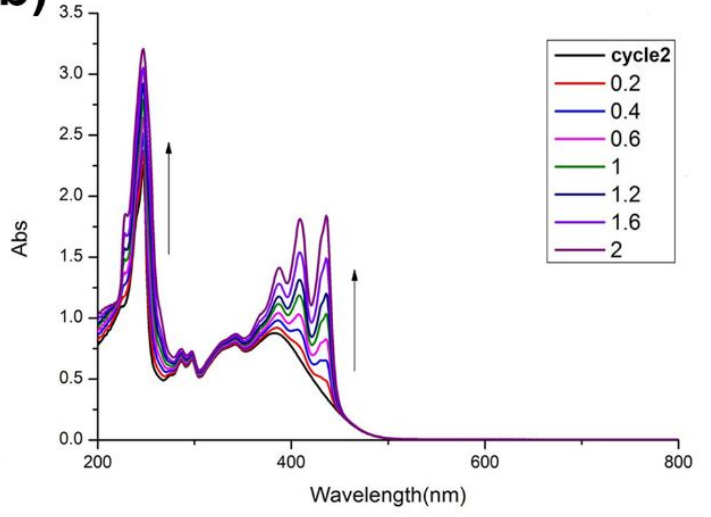

Figure S11. Absorption spectra of (a) 1 and (b) 2 titrated with perylene (0-2 eq.) in $\mathrm{CH}_{2} \mathrm{Cl}_{2 \cdot}[\mathbf{1}]=[2]=1.0 \times 10^{-5} \mathrm{M}$.

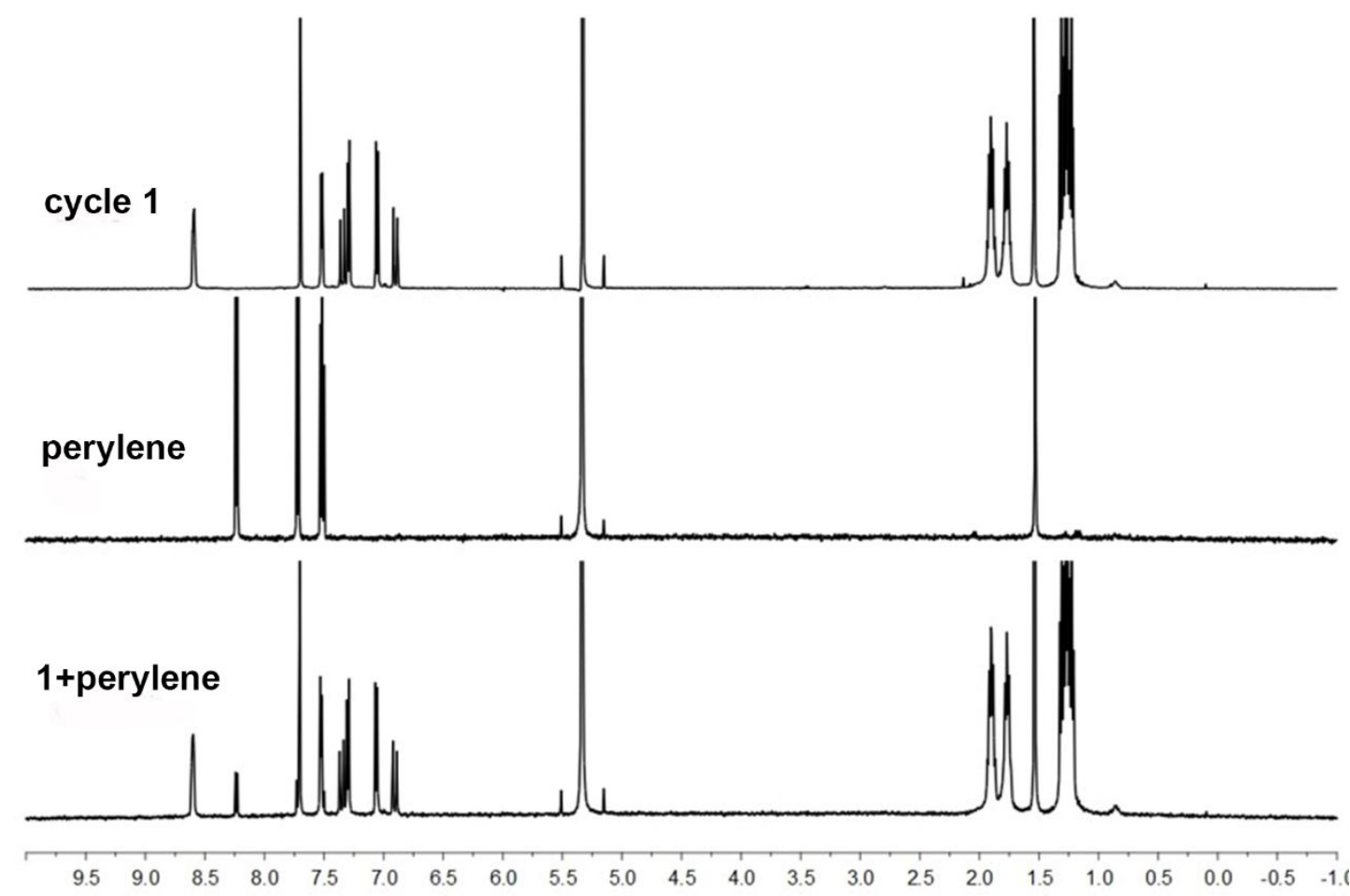

Figure S12. ${ }^{1} \mathrm{H} \mathrm{NMR}\left(\mathrm{CD}_{2} \mathrm{Cl}_{2}\right.$, room temperature, $\left.400 \mathrm{MHz}\right)$ of 1 and perylene. 


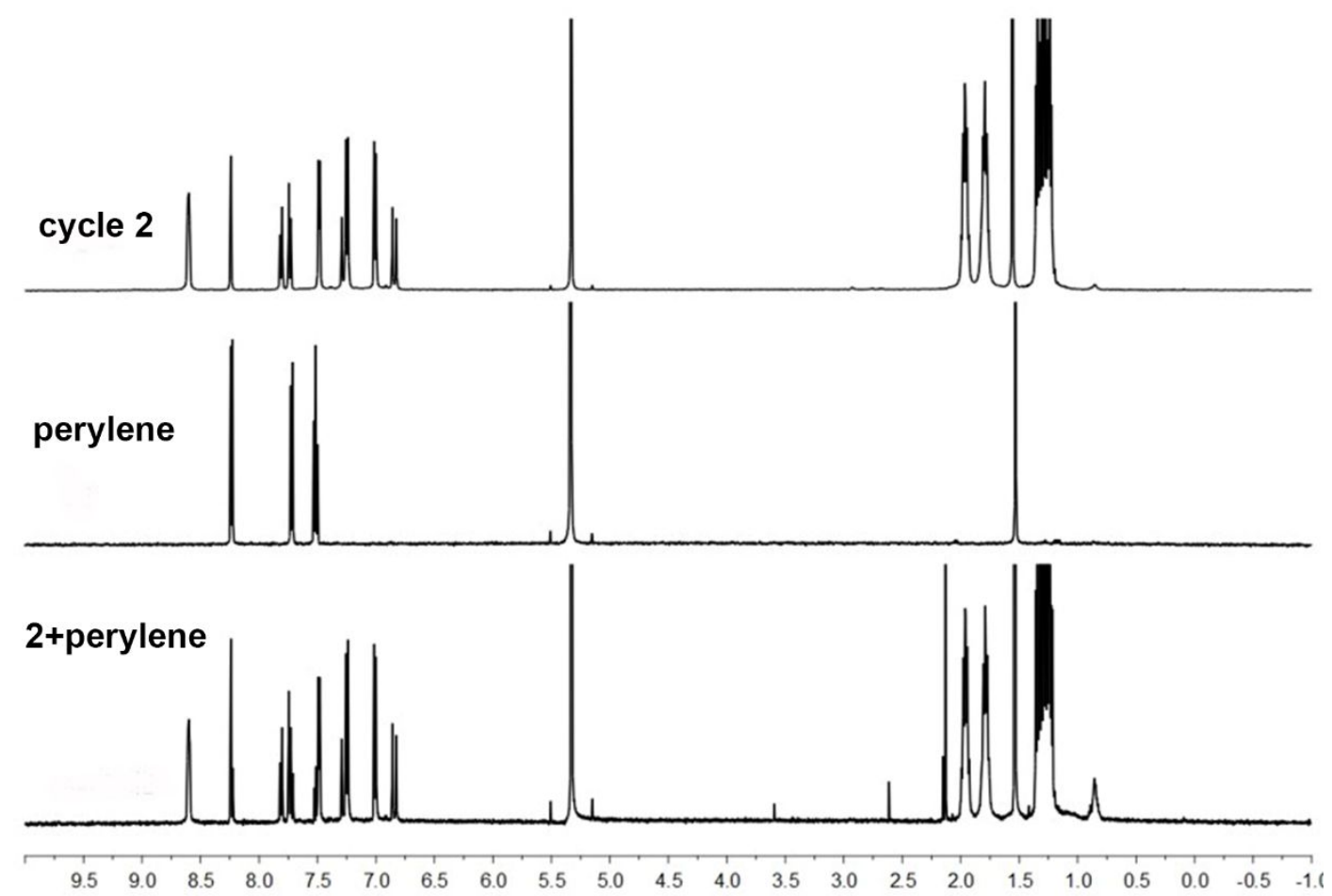

Figure S13. ${ }^{1} \mathrm{H} \mathrm{NMR}\left(\mathrm{CD}_{2} \mathrm{Cl}_{2}\right.$, room temperature, $\left.400 \mathrm{MHz}\right)$ of 2 and perylene.

\section{References}

1. Li, Y.; Dong, Y.; Miao, X.; Ren, Y.; Zhang, B.; Wang, P.; Yu, Y.; Li, B.; Isaacs, L.; Cao, L. Shape-Controllable and Fluorescent Supramolecular Organic Frameworks through Aqueous Host-Guest Complexation. Angew. Chem., Int. Ed., 2018, 57, 729733.

2. Yan, X.; Li, S.; Cook, T. R.; Ji, X.; Yao, Y.; Pollock, J. B.; Shi, Y.; Yu, G.; Li, J.; Huang, F. Hierarchical self-assembly: well-defined supramolecular nanostructures and metallohydrogels via amphiphilic discrete organoplatinum (II) metallacycles. J. Am. Chem. Soc. 2013, 135, 14036-14039.

3. Zheng, Y.; Zhao, Z.; Wang, M.; Ghosh, K.; Pollock, J. B.; Cook, T. R.; Stang, P. J. A facile approach toward multicomponent supramolecular structures: selective selfassembly via charge separation. J. Am. Chem. Soc. 2010, 132, 16873-16882. 
4. SAINT; part of Bruker APEX3 software package (version 2017.3-0): Bruker AXS, 2017.

5. SADABS; part of Bruker APEX3 software package (version 2017.3-0): Bruker AXS, 2017.

6. G. M. Sheldrick, Crystal structure refinement with SHELXL. Acta Cryst. 2015, A71, $3-8$.

7. G. M. Sheldrick, SHELXT - Integrated space-group and crystal-structure determination. Acta Cryst. 2015, C71, 3-8.

8. O.V. Dolomanov, L.J. Bourhis, R.J, Gildea, J.A.K. Howard, H. Puschmann, OLEX2: a complete structure solution, refinement and analysis program. J. Appl. Cryst. 2009, $42,339-341$.

9. A. L. Spek, PLATON SQUEEZE: a tool for the calculation of the disordered solvent contribution to the calculated structure factors. Acta Cryst. 2015, C71, 9-19. 